\title{
High proportion of knowlesi malaria in recent malaria cases in Malaysia
}

\author{
Ruhani Yusof', Yee Ling Lau ${ }^{1 *}$, Rohela Mahmud ${ }^{1}$, Mun Yik Fong ${ }^{1}$, Jenarun Jelip², Hie Ung Ngian³, Sahlawati Mustakim4,
} Hani Mat Hussin ${ }^{5}$, Noradilah Marzuki ${ }^{6}$ and Marlindawati Mohd Ali $^{7}$

\begin{abstract}
Background: Plasmodium knowlesi is a simian parasite that has been recognized as the fifth species causing human malaria. Naturally-acquired P. knowlesi infection is widespread among human populations in Southeast Asia. The aim of this epidemiological study was to determine the incidence and distribution of malaria parasites, with a particular focus on human $P$. knowlesi infection in Malaysia.

Methods: A total of 457 microscopically confirmed, malaria-positive blood samples were collected from 22 state and main district hospitals in Malaysia between September 2012 and December 2013. Nested PCR assay targeting the $18 \mathrm{~S}$ rRNA gene was used to determine the infecting Plasmodium species.

Results: A total of 453 samples were positive for Plasmodium species by using nested PCR assay. Plasmodium knowlesi was identified in 256 (56.5\%) samples, followed by 133 (29.4\%) cases of Plasmodium vivax, 49 (10.8\%) cases of Plasmodium falciparum, two (0.4\%) cases of Plasmodium ovale and one (0.2\%) case of Plasmodium malariae. Twelve mixed infections were detected, including P. knowlesi/P. vivax $(n=10), P$. knowlesi/P. falciparum $(n=1)$, and P. falciparum/P. vivax $(n=1)$. Notably, P. knowlesi (Included mixed infections involving P. knowlesi (P. knowlesi/P. vivax and $P$. knowlesi /P. falciparum)) showed the highest proportion in Sabah (84/115 cases, prevalence of 73.0\%), Sarawak (83/120, 69.2\%), Kelantan (42/56, 75.0\%), Pahang (24/25, 96.0\%), Johor (7/9, 77.8\%), and Terengganu (4/5, 80.0\%,). In contrast, the rates of $P$. knowlesi infection in Selangor and Negeri Sembilan were found to be $16.2 \%$ (18/111 cases) and 50.0\% (5/10 cases), respectively. Sample of P. knowlesi was not obtained from Kuala Lumpur, Melaka, Perak, Pulau Pinang, and Perlis during the study period, while a microscopically-positive sample from Kedah was negative by PCR.

Conclusion: In addition to Sabah and Sarawak, which have been known for high prevalence of $P$. knowlesi infection, the findings from this study highlight the widespread distribution of $P$. knowlesi in many Peninsular Malaysia states.
\end{abstract}

Keywords: Malaria distribution, Plasmodium knowlesi, Malaysia Borneo, Peninsular Malaysia, Nested PCR, Microscopy, SSU rRNA gene

\section{Background}

Malaria is one of the most widespread diseases in the world and is endemic throughout tropical and subtropical regions. In 2012, there were an estimated 207 million cases of malaria, causing approximately 627,000 deaths [1]. Moreover, it is thought that as many as 3.4 billion people are at risk for malarial infection, mostly in Africa and Southeast Asia.

\footnotetext{
* Correspondence: lauyeeling@um.edu.my

'Department of Parasitology, Faculty of Medicine, Tropical Infectious Disease Research and Education Center (TIDREC), University of Malaya, 50603 Kuala Lumpur, Malaysia

Full list of author information is available at the end of the article
}

Five Plasmodium species are known to infect humans: Plasmodium falciparum, Plasmodium vivax, Plasmodium malariae, Plasmodium ovale, and Plasmodium knowlesi [2]. Plasmodium falciparum causes the most severe disease and tends to predominate in tropical areas, whereas $P$. vivax is the predominant species outside of Africa.

Malaria constitutes an important public health problem in Malaysia, especially in the states of Sabah and Sarawak, in Borneo island as well as the central interior regions of Peninsular Malaysia (i e, the shared borders of Perak, Pahang and Kelantan), which have a predominantly aboriginal populations. In 2012, there were 4725 cases of malaria including $P$. falciparum ( $\mathrm{n}=897,19 \%), P$. vivax $(\mathrm{n}=1,458$, 
30.9\%), P. malariae ( $\mathrm{n}=485,10.3 \%)$, P. knowlesi $(\mathrm{n}=1813$, $38.4 \%)$, P. ovale ( $\mathrm{n}=8,0.1 \%)$, mix-infection $(\mathrm{n}=64,1.35 \%)$ and $12(0.25 \%)$ malaria-related deaths in Malaysia [1].

Plasmodium knowlesi is a malaria parasite infecting Old World monkeys that is prevalent in Southeast Asia [3]. It has been recognized as the fifth medically important malaria parasite [4]. A large number of naturally acquired human $P$. knowlesi infections were initially reported in the Kapit Division of Sarawak (Malaysia) [5], which were followed by cases in several geographical regions of Southeast Asia. Previous epidemiological studies have revealed that $P$. knowlesi infections occur in Sarawak and Sabah [5,6], Kalimantan, Indonesian Borneo [7], Peninsular Malaysia [8,9] Thailand [10,11], Singapore [12], Philippines [13], Vietnam [14], and Myanmar [15]. These infections occur in forested areas, which is consistent with exposure to the Anopheles species suspected to be responsible for P. knowlesi transmission such as Anopheles hackeri, Anopheles balabacensis, Anopheles cracens and Anopheles latens [16-18].

Plasmodium knowlesi carries high potential of causing severe or fatal diseases [9]. However, this potentially lifethreatening parasite has been frequently misdiagnosed as $P$. malariae via conventional microscopy due to similarities in morphology at certain asexual stages. Indeed, microscopic examination of the asexual stages of Plasmodium on thick and thin blood film is unable to distinguish early trophozoites of $P$. knowlesi from P. falciparum and late erythrocytic stages from P. malariae [5]. Nevertheless, microscopy represents the most commonly used method for detecting malaria parasites and has been considered as the gold standard for diagnosis, especially for detection and management of early cases in Malaysia. However, the precision and reliability of microscopy depends largely on the quality of stained blood films, parasite density and microscopist expertise. Furthermore, it is difficult to detect mixed infections or low parasitaemia using this conventional method, especially for cases involving P. knowlesi. Thus, in the present study, molecular approach was employed to investigate the epidemiology of P. knowlesi in Malaysia. PCR assay has been described as the most sensitive and specific technique for malarial detection and is capable of identifying mixed infections using species-specific primers $[19,20]$.

\section{Methods}

\section{Study sites and sample collection}

This study was approved by the Medical Research Ethic Committee (MREC) Ministry of Health Malaysia and Medical Ethics Committee of University Malaya Medical Centre. This study was conducted at 22 state and district government hospitals all over Malaysia: Raja Perempuan Zainab II Hospital, Kota Bharu; Sultanah Nur Zahirah Hospital, Kuala Terengganu, Terengganu; Tengku Ampuan Afzan Hospital, Kuantan, Pahang; Kuala Lipis Hospital,
Kuala Lipis, Pahang; Jerantut Hospital Jerantut, Pahang; Sultanah Aminah Hospital, Johor Bahru, Johor; Sultanah Fatimah Specialist Hospital, Muar, Johor; Melaka Hospital, Melaka; Tuanku Jaafar Hospital, Seremban, Negeri Sembilan; Tengku Ampuan Rahimah Hospital, Klang, Selangor; Selayang Hospital, Selangor; Sungai Buloh Hospital, Selangor; Raja Permaisuri Bainun Hospital, Ipoh, Perak; Sultanah Bahiyah Hospital, Alor Setar, Kedah; Sultan Abdul Halim Hospital, Sungai Petani, Kedah; Pulau Pinang Hospital, Pulau Pinang; Tuanku Fauziah Hospital, Kangar, Perlis; Sarawak General Hospital, Kuching, Sarawak; Kapit Hospital, Kapit, Sarawak; Kota Bharu Public Health Laboratory, Kota Bharu, Kelantan and the Department of Vector Borne Disease Control Programme, Kota Kinabalu, Sabah (Figure 1).

Four-hundred and fifty-seven microscopically positive malaria blood samples (in EDTA tube), blood spots (drop on 903 Protein Saver Card; Whatman Ltd, NJ, USA) and blood films were collected from the above locations. Microscopic examination of Giemsa-stained thick and thin blood films were carried out by microscopists of the respective hospitals who have no knowledge of the PCR results. Positive malaria samples were sent by mail express to the Department of Parasitology, Faculty of Medicine, University of Malaya. No randomization was applied to the sampling. Due to logistical, as well as personal co-operative difficulties, the original intention of complete recruitment of all malaria patients was not achieved. Nevertheless, sampling encompassing nine states of Malaysia was successfully done.

\section{DNA extraction}

Templates DNA for nested PCR assay were prepared. DNA extraction was performed on $100 \mu \mathrm{l}$ blood collected in EDTA-vacutainer $(\mathrm{n}=352)$ using DNeasy Blood \& Tissue Kit (Qiagen, Germany). DNA extraction from dried blood spots $(n=81)$ and blood smears $(n=24)$ were conducted according to protocols described previously [21,22] to obtain $100 \mu \mathrm{l}$ of purified template DNA. Purified DNA was stored at $-20^{\circ} \mathrm{C}$.

\section{Nested PCR assay}

The species of the malaria parasite in the samples was determined by nested PCR assay. This assay targets the Plasmodium small subunit ribosomal RNA (SSU rRNA) gene. The primers used for the nested PCR assay were identical to those previously published [5]. The reaction mixture for the first PCR step had $2 \mu \mathrm{l}$ of DNA template, $250 \mathrm{nmol} / \mathrm{L}$ of each primer (rPLU 1 and rPLU 5), PCR buffer (50 mmol/L KCl, $10 \mathrm{mmol} / \mathrm{L}$ Tris- $\mathrm{HCl}$ ), $200 \mathrm{mmol} / \mathrm{L}$ of each deoxynucleoside triphosphate, 1.25 units of Taq DNA polymerase (Promega), and nuclease free water to a final volume of $25 \mu \mathrm{l}$. Primary amplification conditions were $94^{\circ} \mathrm{C}$ for $4 \mathrm{~min} ; 35 \mathrm{cycles}$ at $94^{\circ} \mathrm{C}$ for $30 \mathrm{sec}$, annealing 


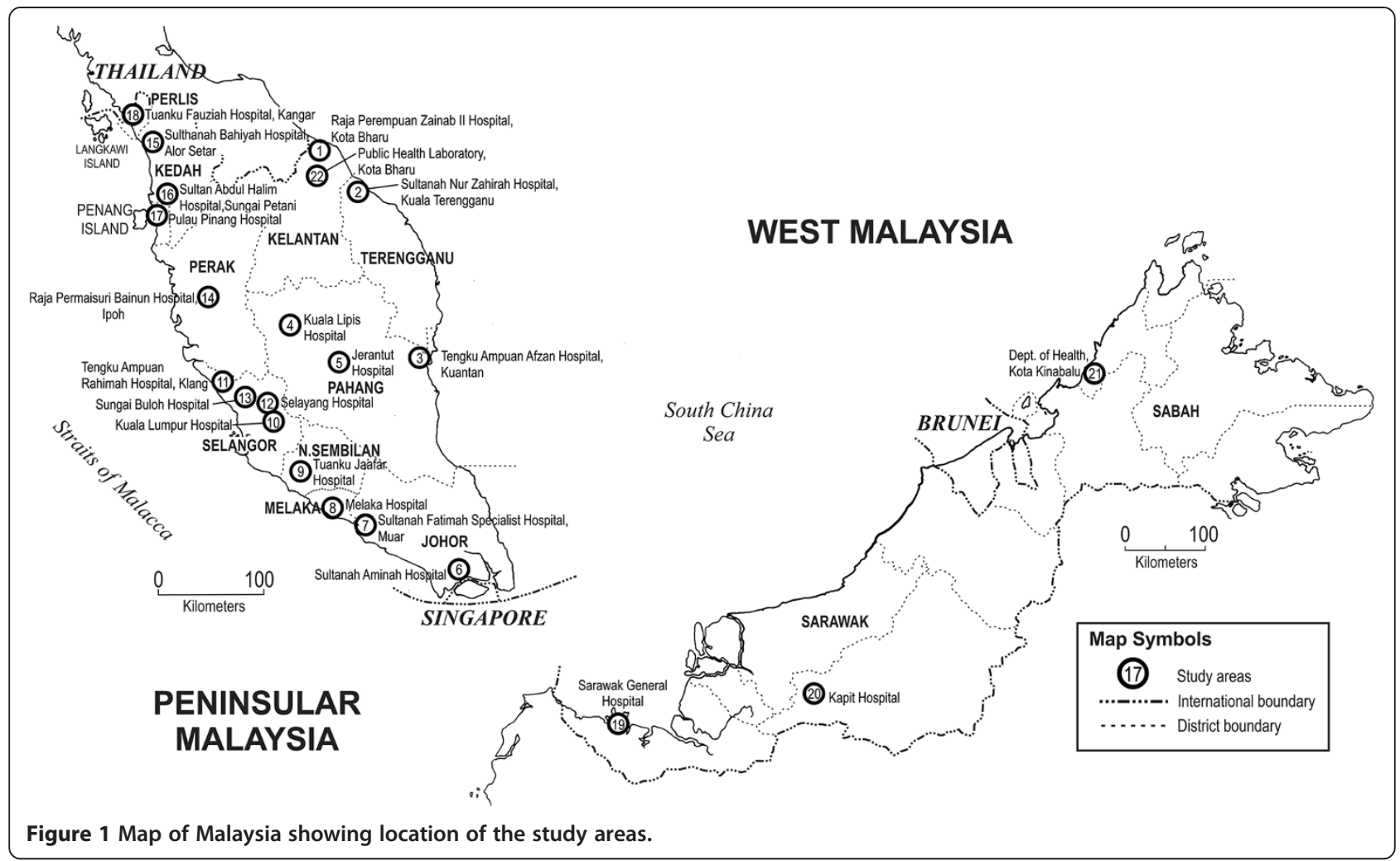

at $55^{\circ} \mathrm{C}$ for $1 \mathrm{~min}$, extension at $72^{\circ} \mathrm{C}$ for $1 \mathrm{~min}$; and final extension at $72^{\circ} \mathrm{C}$ for $4 \mathrm{~min}$. Two $\mu \mathrm{l}$ of the first amplification product was used as DNA template for each of the $20 \mu \mathrm{l}$ secondary amplifications. The conditions and concentrations of the secondary amplification were identical to those of the primary except for the annealing temperature of $58^{\circ} \mathrm{C}$ for species-specific primers (rFAL1/rFAL2, rVIV1/ rVIV2, rMAL1/rMAL2, Pmk8/Pmkr9 and rOVA1/rOVA4) and the amount of Taq Polymerase being 0.5 units. The product was analyzed by agarose gel electrophoresis. All PCR P. knowlesi positive samples were sent to Mytacg Bioscience for DNA sequencing to confirm the species.

\section{Statistical analysis}

Statistical analysis was carried out using the SPSS software programme for Windows version 17 (SPSS, Chicago, IL, USA). A Pearson's Chi-square test was used to test the association between each variable and the confidence interval $(95 \% \mathrm{CI})$ was calculated to explore the association between variables of interest. The level of statistical significance was set at $\mathrm{p}<0.05$ for each test.

\section{Results}

A total of 453 out of 457 samples were positive for Plasmodium sp. based on nested PCR assay (Table 1). Among the Plasmodium species identified, P. knowlesi, P. vivax, $P$. falciparum, P. ovale, and P. malariae were responsible for $56.5 \%$ ( $\mathrm{n}=256), 29.4 \%$ ( $\mathrm{n}=133), 10.8 \%$ ( $\mathrm{n}=49), 0.4 \%$ $(\mathrm{n}=2), 0.2 \%(\mathrm{n}=1)$, respectively. Moreover, 12 mixed infections were detected, including $P$. knowlesi/P. vivax $(\mathrm{n}=10)$, P. knowlesi/P. falciparum $(\mathrm{n}=1)$, and P. falcip$\operatorname{arum} / P$. vivax $(\mathrm{n}=1)$.

Notably, P. knowlesi (included mixed infections involving P. knowlesi (P. knowlesi/P. vivax and P. knowlesi/P. falciparum) showed the high prevalence in Sabah (84 out of 115 cases, proportion of 73.0\%), Sarawak (83 out of 120 cases, 69.2\%), Kelantan (42 out of 56 cases, $75.0 \%$ ), Pahang (24 out of 25 cases, $96.0 \%$ ), Johor (7 out of 9 cases, $77.8 \%$ ), Terengganu (4 out of 5 cases, $80.0 \%$ ). In contrast, the rates of $P$. knowlesi infection in Selangor and Negeri Sembilan were 16.2\% (18 out of 111 cases) and $50.0 \%$ (5 out of 10 cases), respectively. Sample of P. knowlesi was not obtained from Kuala Lumpur, Melaka, Perak, Kedah, Pulau Pinang, and Perlis during the study period, while a microscopically-positive sample from Kedah was negative by PCR (Figure 2).

Among the Plasmodium-positive samples, 56.5\% (256 out of 453) were infected with $P$. knowlesi only, whereas 11 displayed mixed infections involving P. knowlesi (10 P. knowlesi/P. vivax and 1 P. knowlesi/P. falciparum). Many cases of single $P$. knowlesi infection had been microscopically misdiagnosed as other species, including P. malariae ( $\mathrm{n}=72,28.1 \%), P$. $\operatorname{vivax}(\mathrm{n}=8,3.1 \%)$, and $P$. falciparum $(\mathrm{n}=3,1.2 \%)$. Furthermore, 6 mixed infections 
Table 1 PCR-based species profile of malaria cases collected from areas under study

\begin{tabular}{|c|c|c|c|c|c|c|c|c|c|}
\hline \multirow[t]{2}{*}{ States } & \multicolumn{8}{|c|}{ Number of malaria-positive samples by PCR $(\%, 95 \% \mathrm{Cl})$} & \multirow[t]{2}{*}{ Total } \\
\hline & Pf & Pk & Pv & $\mathrm{Pm}$ & Po & $\mathrm{Pv}+\mathrm{Pk}$ & $\mathrm{Pf}+\mathrm{Pk}$ & $P f+P v$ & \\
\hline \multirow[t]{2}{*}{ Sarawak } & 11 & 80 & 25 & 0 & 1 & 3 & 0 & 0 & 120 \\
\hline & $(9.2,6.6-11.8)$ & $(66.7,62.4-71.0)$ & $(20.8,17.1-24.5)$ & (0) & $(0.8,-0.02-1.62)$ & $(2.5,1.1-3.9)$ & (0) & (0) & (100) \\
\hline \multirow[t]{2}{*}{ Sabah } & 14 & 82 & 15 & 1 & 0 & 1 & 1 & 1 & 115 \\
\hline & $(12.2,9.2-15.2)$ & $(71.3,67.1-75.4)$ & $(13.0,9.9-16.1)$ & $(0.9,0.04-1.7)$ & (0) & $(0.9,0.04-1.7)$ & $(0.9,0.04-1.7)$ & $(0.9,0.04-1.7)$ & (100) \\
\hline \multirow[t]{2}{*}{ Selangor } & 18 & 16 & 74 & 0 & 1 & 2 & 0 & 0 & 111 \\
\hline & $(16.2,12.8-19.6)$ & $(14.4,11.2-17.6)$ & $(66.7,62.4-71.0)$ & (0) & $(0.9,0.04-1.7)$ & $(1.8,0.6-3.0)$ & (0) & (0) & (100) \\
\hline \multirow[t]{2}{*}{ Kelantan } & 4 & 40 & 10 & 0 & 0 & 2 & 0 & 0 & 56 \\
\hline & $(7.1,4.7-9.5)$ & $(71.4,67.2-75.5)$ & $(17.9,14.4-21.4)$ & (0) & (0) & $(3.6,1.9-5.3)$ & (0) & (0) & (100) \\
\hline \multirow[t]{2}{*}{ Pahang } & 0 & 24 & 1 & 0 & 0 & 0 & 0 & 0 & 25 \\
\hline & (0) & $(96.0,94.2-97.8)$ & $(4.0,2.2-5.8)$ & (0) & (0) & (0) & (0) & (0) & (100) \\
\hline \multirow[t]{2}{*}{ Negeri Sembilan } & 1 & 4 & 4 & 0 & 0 & 1 & 0 & 0 & 10 \\
\hline & $(10.0,7.2-12.8)$ & $(40.0,35.5-44.5)$ & $(40.0,35.5-44.5)$ & (0) & (0) & $(10.0,7.2-12.8)$ & (0) & (0) & (100) \\
\hline \multirow[t]{2}{*}{ Johor } & 0 & 6 & 2 & 0 & 0 & 1 & 0 & 0 & 9 \\
\hline & (0) & $(66.7,62.4-71.0)$ & $(22.2,18.4-26.0)$ & (0) & (0) & $(11.1,8.2-14.0)$ & (0) & (0) & (100) \\
\hline \multirow[t]{2}{*}{ Kedah } & 1 & 0 & 1 & 0 & 0 & 0 & 0 & 0 & 2 \\
\hline & $(50.0,45.4-54.6)$ & (0) & $(50.0,45.4-54.6)$ & (0) & (0) & (0) & (0) & (0) & (100) \\
\hline \multirow[t]{2}{*}{ Terengganu } & 0 & 4 & 1 & 0 & 0 & 0 & 0 & 0 & 5 \\
\hline & (0) & $(80.0,68-72)$ & $(20.0,16.3-23.7)$ & (0) & (0) & (0) & (0) & (0) & (100) \\
\hline \multirow[t]{2}{*}{ Total } & 49 & 256 & 133 & 1 & 2 & 10 & 1 & 1 & 453 \\
\hline & $(10.8,7.2-13.7)$ & $(56.5,51.9-61.1)$ & $(29.4,25.2-33.6)$ & $(0.2,-0.2-0.6)$ & $(0.4,-0.18-0.98)$ & $(2.2,0.9-3.6)$ & $(0.2,-0.2-0.6)$ & $(0.2,-0.2-0.6)$ & (100) \\
\hline
\end{tabular}




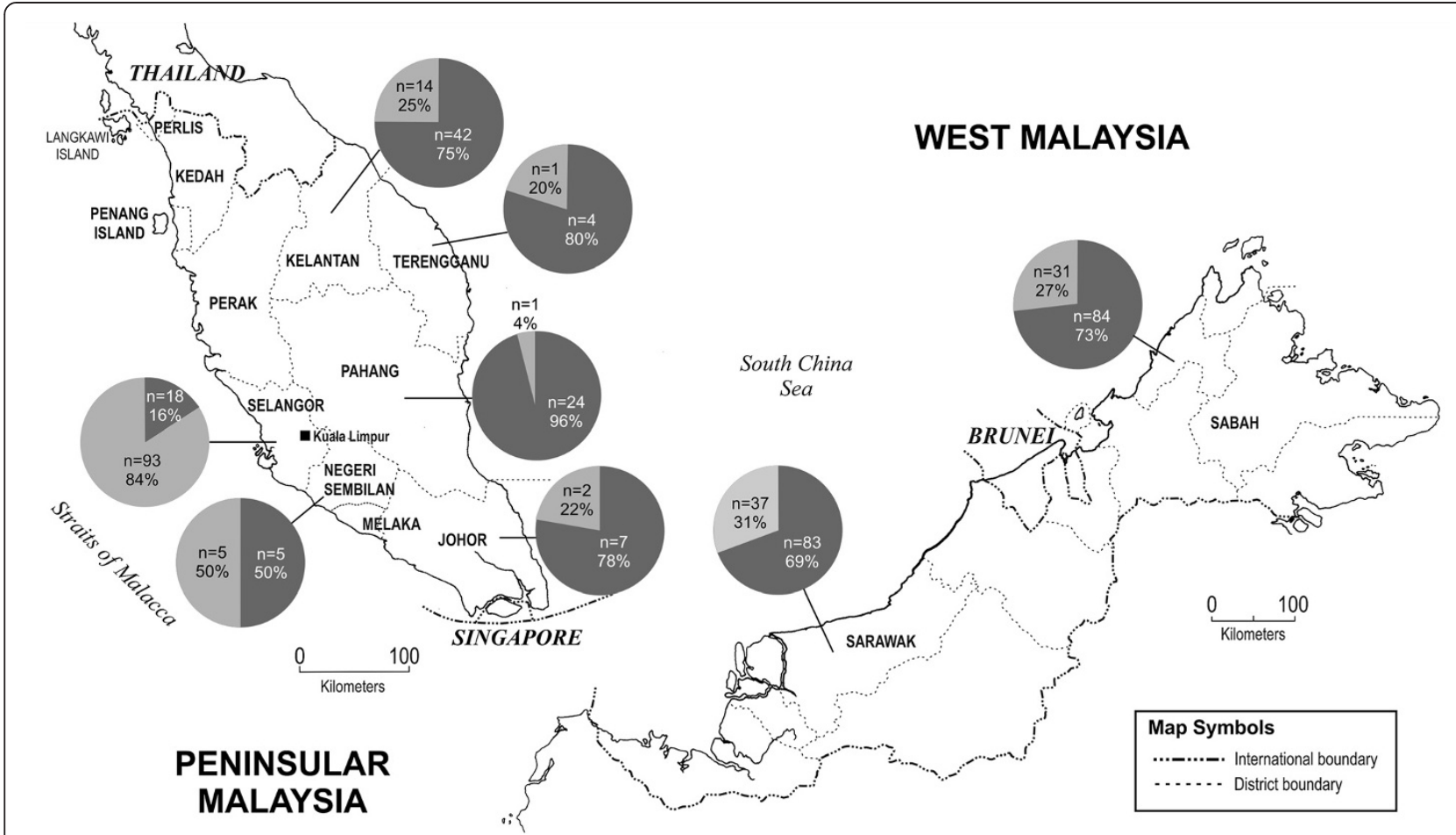

Figure 2 Map of Malaysia showing location of the positive Plasmodium knowlesi areas. Pie charts represent number of cases and percentages of $P$. knowlesi (black) and non-P. knowlesi (grey) malaria infections determined by species-specific nested PCR.

involving $P$. knowlesi (with either $P$. falciparum or $P$. vivax) were misdiagnosed microscopically as single $P$. falciparum $(\mathrm{n}=3)$, single $P$. vivax $(\mathrm{n}=2)$, or single $P$. malariae $(\mathrm{n}=1)$ infections and five cases of mixed infection (i.e. $P$. knowlesi/P. vivax) were misdiagnosed microscopically as single P. knowlesi (Table 2).

In addition, the PCR method revealed that six cases of $P$. vivax and one case of dangerous $P$. falciparum had been wrongly identified as $P$. malariae, which is less threatening. Also, two cases of $P$. ovale infection were considered to be
$P$. vivax by microscopy, whereas a case of $P$. vivax was considered to be $P$. ovale. Other than that, cases of $P$. falciparum and $P$. vivax (one each) were diagnosed as $P$. knowlesi. Notably there were other cases of single P. knowlesi and $P$. vivax had been wrongly identified as mixed infection; P. falciparum/P. malariae and P. knowlesi/P. vivax respectively (Table 2). However in this study, four microscopically malaria-positive cases (one $P$. falciparum and three $P$. knowlesi) were negative when tested by nested PCR assay.

Table 2 Detection of Plasmodium species by microscopy and polymerase chain reaction (PCR) methods in 453 patients with malaria in Malaysia

\begin{tabular}{|c|c|c|c|c|c|c|c|c|}
\hline \multirow[b]{2}{*}{ PCR results } & \multicolumn{7}{|c|}{ Result of microscopic examination } & \multirow[b]{2}{*}{ No. of cases by PCR } \\
\hline & $P f$ & $P k$ & $P v$ & $P m$ & Po & $P k+P v$ & $P f+P m$ & \\
\hline P. falciparum & 46 & 1 & 1 & 1 & 0 & 0 & 0 & 49 \\
\hline P. vivax & 0 & 3 & 122 & 6 & 1 & 1 & 0 & 133 \\
\hline P. malariae & 0 & 0 & 1 & 0 & 0 & 0 & 0 & 1 \\
\hline P. ovale & 0 & 0 & 2 & 0 & 0 & 0 & 0 & 2 \\
\hline P. knowlesi & 3 & 172 & 8 & 72 & 0 & 0 & 1 & 256 \\
\hline P. knowlesi and P. vivax & 2 & 5 & 2 & 1 & 0 & 0 & 0 & 10 \\
\hline P. knowlesi and P. falciparum & 1 & 0 & 0 & 0 & 0 & 0 & 0 & 1 \\
\hline P. falciparum and $P$. vivax & 0 & 0 & 1 & 0 & 0 & 0 & 0 & 1 \\
\hline No. of cases by microscopy & 52 & 181 & 136 & 81 & 1 & 1 & 1 & 453 \\
\hline
\end{tabular}


The age and gender distribution of malaria cases were characterized (Table 3). There was no significant association between age, gender and malaria reported cases. Plasmodium knowlesi infections were detected within all age groups of the study populations, with the youngest being six months old and the oldest being 82 years old (mean = 33.8 years; median $=30.0$ years). The infection was more prevalent among adults (Table 4); the highest proportion (28.5\%) was among patients between 21 and 30 years old. There was a significant difference $(\mathrm{p}=0.008)$ detected among the age groups infected by P. knowlesi (Table 5). The percentage of male patients $(77.9 \%)$ was higher compared to female patients (22.1\%) (Table 6).

\section{Discussion}

Laboratory diagnosis of malaria in disease-endemic countries routinely relies on microscopic detection of parasites in blood smears. The discovery of $P$. knowlesi in humans, which is commonly misdiagnosed as $P$. malariae by microscopy due to morphological similarities, has contributed to a fundamental need for improved diagnostic methods for differentiating malaria parasites [9]. In this regard, $P$. knowlesi-specific primers [5] can be used to accurately identify $P$. knowlesi infections using nested PCR assays, which are more sensitive and specific than microscopy $[20,23]$. However, nested PCR is not yet appropriate for routine clinical use because it is expensive, time-consuming, and nonquantitative. In addition, it requires specialized equipment. Nevertheless, in the present study, the nested PCR technique was successfully used to determine recent incidence of $P$. knowlesi infections in Malaysia.

Recently, significant reduction in malaria cases has been observed and achieved in Malaysia [24]. Malaysia is now striving to be malaria-free in the Peninsular by 2015 and in Malaysian Borneo by 2020 [25]. However, recently, a significant increase in $P$. knowlesi cases was observed in Sabah between 2004 and 2011 and this trend threatens malaria elimination [26].

Based on preliminary study, it is indicated that $P$. knowlesi was accounted for more than half of all cases of malaria in Malaysia. Among the 256 single P. knowlesi infections, 72 (28.1\%) had been microscopically misdiagnosed as $P$. malariae. PCR findings also demonstrated that $P$. knowlesi were detected in almost all cases of microscopically identified $P$. malariae infections. $P$. knowlesi cases that were microscopically misdiagnosed as $P$. malariae were not found in Pahang and Kelantan. Meanwhile, only three cases of $P$. knowlesi infection were misdiagnosed as

Table 3 Age- and gender-based distribution of malaria cases in the area under study

\begin{tabular}{|c|c|c|c|c|c|c|c|c|c|c|c|c|}
\hline \multirow[t]{2}{*}{ States } & \multicolumn{10}{|c|}{ Number of patients according to age groups (\%) } & \multicolumn{2}{|c|}{ Gender (\%) } \\
\hline & $0-10$ & $11-20$ & $21-30$ & $31-40$ & $41-50$ & $51-60$ & $61-70$ & $71-80$ & $81-90$ & Total & Male & Female \\
\hline \multirow[t]{2}{*}{ Sarawak } & 2 & 14 & 18 & 15 & 33 & 26 & 10 & 1 & 1 & 120 & 90 & 30 \\
\hline & $(1.7)$ & $(11.7)$ & $(15.0)$ & $(12.5)$ & $(27.5)$ & $(21.7)$ & $(8.3)$ & $(0.8)$ & $(0.8)$ & $(100.0)$ & $(75.0)$ & $(25.0)$ \\
\hline \multirow[t]{2}{*}{ Sabah } & 10 & 22 & 31 & 15 & 18 & 12 & 6 & 1 & 0 & 115 & 90 & 25 \\
\hline & $(8.7)$ & $(19.1)$ & $(27.0)$ & (13.0) & $(15.7)$ & $(10.4)$ & $(5.2)$ & $(0.9)$ & (0) & $(100.0)$ & (78.3) & $(21.7)$ \\
\hline \multirow[t]{2}{*}{ Selangor } & 0 & 13 & 69 & 19 & 8 & 2 & 0 & 0 & 0 & 111 & 92 & 19 \\
\hline & (0) & $(11.7)$ & $(62.2)$ & $(17.1)$ & $(7.2)$ & $(1.8)$ & (0) & (0) & (0) & $(100.0)$ & $(82.9)$ & $(17.1)$ \\
\hline \multirow[t]{2}{*}{ Kelantan } & 2 & 5 & 27 & 11 & 10 & 1 & 0 & 0 & 0 & 56 & 43 & 13 \\
\hline & (3.6) & (8.9) & $(48.2)$ & (19.6) & $(17.9)$ & $(1.8)$ & (0) & (0) & (0) & $(100.0)$ & (76.8) & $(23.2)$ \\
\hline \multirow[t]{2}{*}{ Pahang } & 0 & 1 & 8 & 9 & 6 & 1 & 0 & 0 & 0 & 25 & 19 & 6 \\
\hline & (0) & $(4.0)$ & $(32.0)$ & $(36.0)$ & $(24.0)$ & $(4.0)$ & (0) & (0) & (0) & $(100.0)$ & $(76.0)$ & $(24.0)$ \\
\hline \multirow[t]{2}{*}{ Negeri Sembilan } & 1 & 1 & 3 & 3 & 1 & 1 & 0 & 0 & 0 & 10 & 9 & 1 \\
\hline & $(10.0)$ & $(10.0)$ & $(30.0)$ & $(30.0)$ & $(10.0)$ & $(10.0)$ & (0) & (0) & (0) & $(100.0)$ & $(90.0)$ & $(10.0)$ \\
\hline \multirow[t]{2}{*}{ Johor } & 0 & 1 & 1 & 6 & 0 & 0 & 1 & 0 & 0 & 9 & 8 & 1 \\
\hline & (0) & (11.1) & $(11.1)$ & $(66.7)$ & (0) & (0) & $(11.1)$ & $(0)$ & (0) & $(100.0)$ & $(88.9)$ & $(11.1)$ \\
\hline \multirow[t]{2}{*}{ Kedah } & 0 & 1 & 1 & 0 & 0 & 0 & 0 & 0 & 0 & 2 & 2 & 0 \\
\hline & (0) & $(50.0)$ & $(50.0)$ & (0) & (0) & (0) & (0) & (0) & (0) & $(100.0)$ & $(100.0)$ & (0) \\
\hline \multirow[t]{2}{*}{ Terengganu } & 0 & 1 & 2 & 1 & 0 & 1 & 0 & 0 & 0 & 5 & 4 & 1 \\
\hline & (0) & $(20.0)$ & $(40.0)$ & $(20.0)$ & (0) & $(20.0)$ & (0) & (0) & (0) & $(100.0)$ & $(80.0)$ & $(20.0)$ \\
\hline \multirow[t]{2}{*}{ Total } & 15 & 59 & 160 & 79 & 76 & 44 & 17 & 2 & 1 & 453 & 357 & 96 \\
\hline & (3.3) & (13.0) & (35.3) & $(17.4)$ & $(16.8)$ & $(9.7)$ & (3.8) & $(0.4)$ & $(0.2)$ & $(100.0)$ & (78.8) & $(21.2)$ \\
\hline$X^{2}, P$ & \multicolumn{10}{|c|}{$52,8,0.597$} & \multicolumn{2}{|c|}{$10.6,0.158$} \\
\hline
\end{tabular}


Table 4 Distribution of Plasmodium knowlesi according to age group (children and adult) diagnosed by PCR

\begin{tabular}{lll}
\hline Age (year) & Number & Percentage \\
\hline Children (0-14) & 18 & $6.7 \%$ \\
Adult (>15 years) & 249 & $93.3 \%$ \\
$X^{2}$ & & 0.15 \\
P & & 0.903 \\
*Total & 267 & 100 \\
\hline
\end{tabular}

*Including mixed infections involving $P$. knowlesi.

P. malariae in Sarawak. However, most of the P. knowlesi infections in Sabah were misdiagnosed as $P$. malariae by microscopic examination. The decrease in microscopy diagnostic discrepancy is due to the increased awareness about $P$. knowlesi infections among the local laboratory technicians and microscopists. Coupled with the fact that P. malariae infection is not frequently found in Malaysia, the encounter of malaria parasites with morphology similar to that of P. malariae has been reported as "P. knowlesi" infection by default. In addition, clinical data such as the relatively high parasitaemia and low platelet reading serve as useful guides in diagnosing $P$. knowlesi infection as well.

From this study, it is clearly demonstrated that PCR represents a more sensitive and specific method for detecting mixed infections, which tend to be overlooked in the microscopy-based assay, especially when one of the species is present at a lower density. Moreover, PCR allows specific identification of $P$. knowlesi, which sometimes cannot be accurately diagnosed by microscopic examination. The negative nested PCR results yielded from the four microscopically malaria-positive cases were likely to be caused by DNA degradation of the samples. Coincidently, these four samples were DNA templates extracted from the blood smears, indicating the relatively inferior

Table 5 Distribution of Plasmodium knowlesi according to age group diagnosed by PCR

\begin{tabular}{lll}
\hline Age group & Number & Percentage \\
\hline $0-10$ & 10 & $3.7 \%$ \\
$11-20$ & 34 & $12.7 \%$ \\
$21-30$ & 76 & $28.5 \%$ \\
$31-40$ & 46 & $17.2 \%$ \\
$41-50$ & 53 & $19.9 \%$ \\
$51-60$ & 32 & $12 \%$ \\
$61-70$ & 14 & $5.2 \%$ \\
$71-80$ & 1 & $0.4 \%$ \\
$81-90$ & 1 & $0.4 \%$ \\
$X^{2}$ & & 20.8 \\
$P$ & & 0.008 \\
Total & 267 & 100 \\
\hline
\end{tabular}

Table 6 Distribution of Plasmodium knowlesi according to gender diagnosed by PCR

\begin{tabular}{lll}
\hline Gender & Number & Percentage \\
\hline Male & 208 & $77.9 \%$ \\
Female & 59 & $22.1 \%$ \\
$X^{2}$ & & 0.57 \\
$P$ & & 0.32 \\
Total & 267 & 100 \\
\hline
\end{tabular}

quality of DNA extracted from blood smears, as pointed out by previous studies $[27,28]$. Nevertheless, blood smears still serve as a good source of DNA extraction [22], especially for samples from isolated locations that are hard to reach.

The PCR primers (Pmk8 and Pmk9) used for P. knowlesi detection in this study were not the most recently developed primers. Issues regarding non-specific binding of these primers to $P$. vivax were reported previously [29]. Nevertheless, the specificity of PCR primer binding is influenced by many confounding factors and may vary from one laboratory to another, as well as from one PCR machine to another. For further confirmation of the nested PCR results, DNA sequencing on the PCR amplicons from primers rPLU 5 and rPLU 6 (size $\sim 1200 \mathrm{bp}$ ) were conducted. Based on sequencing, all malaria-positive samples identified as $P$. knowlesi-positive by the Pmk 8 and Pmkr9 primers were indeed $P$. knowlesi-infected samples.

From this study, patients ranged from young children to the elderly; however, this infection was more prevalent among adults, especially males. Only a small proportion of cases occurred in children; this may be related to the limited outdoor or forest activities by this group of patients. A previous study postulated that the transmission of P. knowlesi may occur from human to human due to the discovery of family clustering cases [30]. Nevertheless, no clustering of $P$. knowlesi cases was found in the present study. The infection was more prevalent among adults (Table 4) with a significant difference of $\mathrm{p}=0.008$ detected among the age groups (Table 5) infected with P. knowlesi. The highest rate of infection (28.5\%) occured in patients in the age group of 21 to 30 (Table 5) who presumably are more active outdoors and more at risk of being bitten by an infected mosquito. This finding is in agreement with the inference stated by [31] that P. knowlesi infection is obtained from mosquito fed on infected monkey and not from humans.

Early P. knowlesi trophozoites (delicate ring) display morphological similarities to $P$. falciparum, while other blood stages are identical to $P$. malariae [5,9], resulting in misdiagnoses. In fact, the present study confirms that $P$. knowlesi could be misdiagnosed as P. malariae (majority), $P$. falciparum, $P$. vivax, or mixed infections (i e, P. falciparum/P. malariae). As $P$. knowlesi displays the 
shortest replication cycle of all known human and nonhuman primate malarias ( 24 hours), malaria caused by this species is potentially fatal [32]. Therefore, timely diagnosis and treatment are crucial for reducing the risk of complications. Unfortunately, misdiagnosis of potentially lethal $P$. knowlesi as $P$. malariae may result in delayed treatment [9]. For this reason, accurate identification of Plasmodium species is fundamental for proper clinical management and control strategies. In addition, any case demonstrating "P. malariae-like parasites" should be treated presumably as "P. knowlesi infection" while waiting for the molecular confirmation diagnosis.

\section{Conclusion}

In addition to Sabah and Sarawak, which have high record of $P$. knowlesi infection, the present investigation highlights the widespread distribution of human knowlesi malaria in Peninsular Malaysia (Kelantan, Pahang, Selangor, Johor and Negeri Sembilan). In fact, P. knowlesi was found to be the most prevalent Plasmodium parasite infecting the population of Sabah and Sarawak (Malaysia Borneo) as well as Peninsular Malaysia. Accurate epidemiological data serve as an important foundation for developing effective control strategies for malaria. The present study has provided critical data that contribute to the better understanding on the distribution of $P$. knowlesi within the interior division of Sabah and Sarawak and central regions of Peninsular Malaysia.

\section{Consent}

Consent was granted by patient/patient's family for the publication of these case reports.

\section{Competing interests}

The authors declare that they have no competing interests.

\section{Authors' contributions}

RY, JJ, HUG, SM, HMH, NM and MMA collected blood samples and patients' data. RY, and YLL analyzed and interpreted the data. RY, YLL, RM and MYF arranged the data, conceptualized and prepared the manuscript. All authors read and approved the final manuscript.

\section{Acknowledgements \\ The authors thank Medical Research Ethic Committee (MREC) Ministry of Health Malaysia, Sabah State Director of Health, Kelantan State Director of Health, Directors of State and District Hospitals for approving this study, the technical staff in study sites, especially Hanapi Seli, Isma Lyna Ismail, Zubaidah Abdul Wahab, Lim Bee Bee, Fatimah Haslina Abdullah, Azizah Mustafa, Kartina Md. Noor, Azizon Othman, Masturah Che Abdullah Hairolafizah Sebeki, and Sarimah Hashim for their assistance in collecting sample and assistance in the laboratory work (microscopic observation). This study funded by University of Malaya High Impact Research Fund UM-MOHE (UM.C/625/1/HIR/MOHE/CHAN/14/3 and UM.C/HIR/MOHE/MED/16) from the Ministry of Higher Education, Malaysia and Post-graduate Research Grant (PV044/2012A).}

\section{Author details}

${ }^{1}$ Department of Parasitology, Faculty of Medicine, Tropical Infectious Disease Research and Education Center (TIDREC), University of Malaya, 50603 Kuala Lumpur, Malaysia. ${ }^{2}$ Sabah State Health Department, Tingkat 1, 3 \& 6, Rumah Persekutuan, Jalan Mat Salleh, 88590 Kota Kinabalu, Sabah, Malaysia. ${ }^{3}$ Hospital
Kapit, Jalan Mamora, 96800 Kapit, Sarawak, Malaysia. ${ }^{4}$ Microbiology Laboratory, Department of Pathology, Hospital Tengku Ampuan Rahimah, Jalan Langat, 41200 Klang, Selangor, Malaysia. ${ }^{5}$ Kelantan State Health Department, Aras 5, Wisma Persekutuan, Jalan Bayam, 15590 Kota Bharu, Kelantan, Malaysia. ${ }^{6}$ Department of Pathology, Hospital Kuala Lipis, 27200 Kuala Lipis, Pahang, Malaysia. ${ }^{7}$ Department of Pathology, Hospital Tuanku Ja'afar Jalan Rasah, 70300 Seremban, Negeri Sembilan, Malaysia.

Received: 17 February 2014 Accepted: 28 April 2014

Published: 3 May 2014

\section{References}

1. WHO: World Malaria Report. Geneva: World Health Organization; 2013.

2. Nishimoto Y, Arisue N, Kawai S, Escalante AA, Horii T, Tanabe K, Hashimoto T: Evolution and phylogeny of the heterogeneous cytosolic SSU rRNA genes in the genus Plasmodium. Mol Phylogenet Evol 2008, 47:45-53.

3. Garnham PC: A new sub-species of Plasmodium knowlesi in the long-tailed macaque. J Trop Med Hyg 1963, 66:156-158.

4. White NJ: Plasmodium knowlesi: the fifth human malaria parasite. Clin Infect Dis 2008, 46:172-173.

5. Singh B, Kim Sung L, Matusop A, Radhakrishnan A, Shamsul SS, Cox-Singh J, Thomas A, Conway DJ: A large focus of naturally acquired Plasmodium knowlesi infections in human beings. Lancet 2004, 363:1017-1024.

6. Lee KS, Cox-Singh J, Brooke G, Matusop A, Singh B: Plasmodium knowlesi from archival blood films: further evidence that human infections are widely distributed and not newly emergent in Malaysian Borneo. Int $J$ Parasitol 2009, 39:1125-1128.

7. Sulistyaningsih $E$, Fitri LE, Loscher $T$, Berens-Riha N: Diagnostic difficulties with Plasmodium knowlesi infection in humans. Emerg Infect Dis 2010, 16:1033-1034.

8. Vythilingam I, Noorazian YM, Huat TC, Jiram Al, Yusri YM, Azahari AH, Norparina I, Noorrain A, Lokmanhakim S: Plasmodium knowlesi in humans, macaques and mosquitoes in peninsular Malaysia. Parasit Vectors 2008, 1:26.

9. Cox-Singh J, Davis TM, Lee KS, Shamsul SS, Matusop A, Ratnam S, Rahman HA, Conway DJ, Singh B: Plasmodium knowlesi malaria in humans is widely distributed and potentially life threatening. Clin Infect Dis 2008, 46:165-171.

10. Putaporntip C, Thongaree S, Jongwutiwes S: Differential sequence diversity at merozoite surface protein-1 locus of Plasmodium knowlesi from humans and macaques in Thailand. Infect Genet Evol 2013, 18:213-219.

11. Jongwutiwes S, Putaporntip C, Iwasaki T, Sata T, Kanbara H: Naturally acquired Plasmodium knowlesi malaria in human, Thailand. Emerg Infect Dis 2004, 10:2211-2213.

12. Ng OT, Ooi EE, Lee CC, Lee PJ, Ng LC, Pei SW, Tu TM, Loh JP, Leo YS: Naturally acquired human Plasmodium knowlesi infection, Singapore. Emerg Infect Dis 2008, 14:814-816.

13. Luchavez J, Espino F, Curameng P, Espina R, Bell D, Chiodini P, Nolder D, Sutherland C, Lee KS, Singh B: Human infections with Plasmodium knowlesi, the Philippines. Emerg Infect Dis 2008, 14:811-813.

14. van den Eede $P$, Van $H N$, van Overmeir C, Vythilingam I, Duc TN, Hung le $X$, Manh HN, Anne J, D'Alessandro U, Erhart A: Human Plasmodium knowlesi infections in young children in central Vietnam. Malar J 2009, 8:249.

15. Jiang N, Chang Q, Sun X, Lu H, Yin J, Zhang Z, Wahlgren M, Chen Q: Co-infections with Plasmodium knowlesi and other malaria parasites, Myanmar. Emerg Infect Dis 2010, 16:1476-1478.

16. Jiram Al, Vythilingam I, NoorAzian YM, Yusof YM, Azahari AH, Fong MY: Entomologic investigation of Plasmodium knowlesi vectors in Kuala Lipis, Pahang, Malaysia. Malar J 2012, 11:213.

17. Vythilingam I, Tan CH, Asmad M, Chan ST, Lee KS, Singh B: Natural transmission of Plasmodium knowlesi to humans by Anopheles latens in Sarawak, Malaysia. Trans R Soc Trop Med Hyg 2006, 100:1087-1088.

18. Vythilingam I: Plasmodium knowlesi in humans: a review on the role of its vectors in Malaysia. Trop Biomed 2010, 27:1-12.

19. Snounou G, Viriyakosol S, Zhu XP, Jarra W, Pinheiro L, do Rosario VE, Thaithong S, Brown KN: High sensitivity of detection of human malaria parasites by the use of nested polymerase chain reaction. Mol Biochem Parasitol 1993, 61:315-320.

20. Singh B, Bobogare A, Cox-Singh J, Snounou G, Abdullah MS, Rahman HA: A genus- and species-specific nested polymerase chain reaction malaria 
detection assay for epidemiologic studies. Am J Trop Med Hyg 1999, 60:687-692.

21. Fischer A, Lejczak C, Lambert C, Servais J, Makombe N, Rusine J, Staub T, Hemmer R, Schneider F, Schmit JC, Arendt V: Simple DNA extraction method for dried blood spots and comparison of two PCR assays for diagnosis of vertical human immunodeficiency virus type 1 transmission in Rwanda. J Clin Microbiol 2004, 42:16-20.

22. Cnops L, van Esbroeck M, Bottieau E, Jacobs J: Giemsa-stained thick blood films as a source of DNA for Plasmodium species-specific real-time PCR. Malar J 2010, 9:370.

23. Singh B: Molecular methods for diagnosis and epidemiological studies of parasitic infections. Int J Parasitol 1997, 27:1135-1145.

24. WHO: World Malaria Report. Geneva: World Health Organization; 2011.

25. Atlas of Asia Pacific Malaria Elimination Network (APMEN). 2011: Available http://apmen.org/storage/atlas/Malaysia.pdf. Accessed 3rd January 2012.

26. William T, Rahman HA, Jelip J, Ibrahim MY, Menon J, Grigg MJ, Yeo TW, Anstey NM, Barber BE: Increasing incidence of Plasmodium knowlesi malaria following control of $P$. falciparum and $P$. vivax Malaria in Sabah, Malaysia. PLoS Negl Trop Dis 2013, 7:e2026.

27. Yokota MTN, Tsuda I, Yano I: DNA extraction and amplification from Giemsa-stained blood smears. J Clin Lab Anal 1995, 9:387-391.

28. Scopel KKG, Fontes CJF, Nunes ÁC, de Fátima Horta M, Braga ÉM: Low sensitivity of nested PCR using Plasmodium DNA extracted from stained thick blood smears: an epidemiological retrospective study among subjects with low parasitaemia in an endemic area of the Brazilian Amazon region. Malar J 2004, 3:8.

29. Imwong M, Tanomsing N, Pukrittayakamee S, Day NP, White NJ, Snounou G Spurious amplification of a Plasmodium vivax small-subunit RNA gene by use of primers currently used to detect P. knowlesi. J Clin Microbiol 2009, 47:4173-4175.

30. Barber BE, William T, Dhararaj P, Anderios F, Grigg MJ, Yeo TW, Anstey NM: Epidemiology of Plasmodium knowlesi malaria in north-east Sabah, Malaysia: family clusters and wide age distribution. Malar J 2012, 11:401.

31. Goh XT, Lim YA, Vythilingam I, Chew CH, Lee PC, Ngui R, Tan TC, Yap NJ Nissapatorn V, Chua KH: Increased detection of Plasmodium knowlesi in Sandakan division, Sabah as revealed by PlasmoNex. Malar J 2013, 12:264

32. Chin W, Contacos PG, Collins WE, Jeter MH, Alpert E: Experimental mosquito-transmission of Plasmodium knowlesi to man and monkey. Am J Trop Med Hyg 1968, 17:355-358.

doi:10.1186/1475-2875-13-168

Cite this article as: Yusof et al:: High proportion of knowlesi malaria in recent malaria cases in Malaysia. Malaria Journal 2014 13:168.

\section{Submit your next manuscript to BioMed Central and take full advantage of:}

- Convenient online submission

- Thorough peer review

- No space constraints or color figure charges

- Immediate publication on acceptance

- Inclusion in PubMed, CAS, Scopus and Google Scholar

- Research which is freely available for redistribution

Submit your manuscript at www.biomedcentral.com/submit
Biomed Central 